\title{
IASPM@Journal
}

Journal of the International Association for the Study of Popular Music

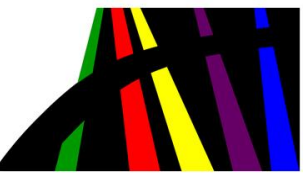

\section{Languages of Global Hip Hop}

\author{
Marina Terkourafi (Ed.) \\ London: Continuum, 2010 \\ ISBN 9781441140265 (PB) \\ RRP: $£ 30.00$ (GBP)
}

\section{Catherine Baker \\ University of Hull \\ cbakertw1@googlemail.com}

In popular music studies, hip hop stands out among musical genres for its diverse linguistic practices. The creativity with which many rappers combine the resources of languages, dialects and slang available to them is not just an expression of artistic flair but also, as popular music researchers have been arguing since the mid-1990s, a dramatisation of mixed identities which seeks to turn national musical cultures into transnational musical spaces in contexts around the world. Tony Mitchell (1998: 41), for instance, points to "local indigenizations of the global musical idiom of rap" and, in particular, to examples of "resistance vernaculars", which take up local concerns, such as the marginalisation of the French banlieves or the colonial oppression of the Maori people.

Sociolinguistics has also, and for the same reasons, developed an enthusiastic interest in hip-hop. The global hip hop discography is rich with case studies revealing the politics of language choice, and how language policy and the market may constrain or facilitate rappers' decisions; it provides a whole new corpus of evidence for the study of "code-switching," that is, the act of switching between languages within a single utterance. Jannis Androutsopoulos, among the contributors to this collection, developed a framework for studying vernacular hip-hop in Europe in a well-known article with Arno Scholz (2003). Another sociolinguist, Alastair Pennycook (2007), sees the localization strategies of hip hop as examples of emerging "global Englishes," which challenge the older paradigm of the spread of English as evidence of global cultural homogenisation. H Samy Alim (2009: 106), similarly, perceives hip-hop youth as participating in a global style community "through their use of multiple language varieties and styles." Languages of Global Hip Hop takes this literature as a point of departure, and would be of use to popular researchers from many disciplines who are interested in the same issues.

Marina Terkourafi, a linguist at the University of Illinois, Urbana-Champaign, has developed this collection out of a workshop on Languages and Hip Hop Culture in a Globalizing World that she organised at her home institution in 2007. Contributors to this and a follow-on workshop at the Sociolinguistics Symposium in Amsterdam make up many of the chapters in this book, which is arranged as a succession of case studies from Germany, France, Egypt, Hungary, South Korea, Greece, Cyprus and the USA. The Greek and German linguistic areas are particularly well showcased, appearing in two and three chapters respectively. Almost every chapter is concerned 
with multilingualism on one or other level, whether this is the choice to rap in one language or another (as in Sarah Simeziane's chapter on the Hungarian Roma group

Fekete Vonat), a choice between language variants (as in Evros Stylianou's chapter on the significance of Modern Standard Greek and Greek Cypriot Dialect in Greek Cypriot rap), or intricate patterns of code-switching at stanza level (discussed in most chapters). The two chapters on the USA approach the theme from different angles, looking at the construction of identity through language when rappers use symbols identified with the South or the Midwest (Jennifer Cramer and Jill Hallett) or contest the use of the $\mathrm{N}$-word (Cecilia Cutler).

How far does this collection offer, as Terkourafi suggests in the Introduction, "A Fresh Look at Some Old Questions"? The editor herself feels that "the single theme to make an appearance in chapter after chapter of this volume" is authenticity - the value of "keepin it real" that guides hip-hop musicians. Aside from this, as well as the overall theme of language and identity, the book does not explicitly relate chapters to each other outside the Introduction; this is a collection of case studies rather than a theoretical intervention and, rather than seeking to create a new paradigm for its discipline, it aims to fill in what has already been mapped out by sociolinguists such as Pennycook and Alim. The sites of several case studies are themselves novel within the sociolinguistics of hip hop, and Angela Williams's chapter on language choice and localisation in Egyptian hip hop ends up providing a useful background to the activity of one of the groups featured, Arabian Knightz, during the Egyptian revolution.

More could have been done to advance the conceptual, as well as geographical, novelty of this collection: topics such as the rapper's "dual role of expert/outsider" (5), the use of local narrative styles such as cursing or comedic recital as part of the strategy of localisation, or the possibility that $9 / 11$ has altered existing transcultural flows, are alluded to but not systematically drawn out. A concluding chapter, or even the division of the volume into parts, could potentially have given this volume more theoretical heft.

Languages of Global Hip Hop succeeds, however, in what it has set out to do. This book would sit well in a popular music studies library as a companion volume to works such as Harris M. Berger and Michael Thomas Carroll's collection Global Pop, Local Language (2003), and will be of particular interest where courses cover the Greek or German linguistic areas. Its applications of the literature on which it relies confirm that linguists continue to have much to learn from popular music and from its vernaculars.

\section{References}

Alim, H. Samy (2009) Translocal Style Communities: Hip Hop Youth as Cultural Theorists of Style, Language, and Globalization. Pragmatics, 19 (1): 103-127. http://elanguage.net/journals/pragmatics/article/view/805 Accessed: 14 Aug 2012

Androutsopoulos, Jannis, and Arno Scholz (2003) Spaghetti Funk: Appropriations of Hip-Hop Culture and Rap Music in Europe. Popular Music and Society 26 (4): 463479. http://dx.doi.org/10.1080/0300776032000144922

Berger, Harris M., and Michael Thomas Carroll (2003) Global Pop, Local Language. Jackson: University Press of Mississippi.

Mitchell, Tony (1998) Doin' Damage in My Native Language: The Use of “Resistance Vernaculars" in Hip Hop in France, Italy, and Aotearoa/New Zealand. Popular Music and Society 24 (3): 41-54. http://dx.doi.org/10.1080/03007760008591775

Pennycook, Alastair (2007) Global Englishes and Transcultural Flows. London and New York: Routledge. 